\title{
ПОЛИТИЧЕСКАЯ СТАБИЛЬНОСТЬ
}

\author{
С.М. Иванов
}

DOI: $10.7256 / 2305-560 X .2014 .3 .12169$

\section{СУДЬБА СОВЕТСКИХ КУРДОВ}

\begin{abstract}
Аннотация: Как известно, курды - народ с тысячелетней историей, который в силу различных исторических причин не смог создать своего государства и к началу 19-го века проживал на территориях Османской и Персидской империй. Большая часть курдских племен вела кочевой и полукочевой образ жизни. После заключения в 1828 г. между Россией и Персией Туркманчайского, а в 1829 г. между Россией и Османской империей Адрианопольского договоров - к России отошли часть иранских и турецких территорий, населенных армянами, азербайджанцами и курдами. Районы Ирана (Салмас, Хой, Урмия и др.), а также Турции (Ван, Эрзурум, Карс и др.) вместе со всем населением вошли в состав российского Закавказья. Таким образом, проживавшие там курды стали полноправными поданными Российской империи. Однако следует заметить, что отдельные курдские племена обосновались в Грузии (Месхетии) еще в XVI в., а в начале XIX в. - еще и в окрестностях грузинской крепости Квели. Вошедшие в состав России турецкие и иранские курды оказались лояльны к российским властям, поскольку видели в русских своих освободителей от турецкого и персидского гнета. Не случайно, вскоре многие курды поступили на российскую военную службу и отличились отвагой и храбростью в многочисленных сражениях в ходе русско-турецких войн.
\end{abstract}

Ключевые слова: международные отношения, внешняя политика, СССР, курды, политическая стабильность, дипломатия, государство, нация, безопасность, ченности.

\section{Судьба советских курдов - одного} из коренных народов Закавказья

Как известно, курды - народ с тысячелетней историей, который в силу различных исторических причин не смог создать своего государства, и к началу 19-го века проживал на территориях Османской и Персидской империй. Большая часть курдских племен вела кочевой и полукочевой образ жизни. После заключения в 1828 г. между Россией и Персией Туркманчайского, а в 1829 г. между Россией и Османской империей Адрианопольского договоров к России отошли часть иранских и турецких территорий, населенных армянами, азербайджанцами и курдами. Районы Ирана (Салмас, Хой, Урмия и др.), а также Турции (Ван, Эрзурум, Карс и др.) вместе со всем населением вошли в состав российского Закавказья. Таким образом, проживавшие там курды стали полноправными поданными Российской империи. Однако следует заметить, что отдельные курдские племена обосновались в Грузии (Месхетии) еще в XVI в., а в начале XIX в. - еще и в окрестностях грузинской крепости Квели. Вошедшие в состав России турецкие и иранские курды оказались лояльны к российским властям, поскольку видели в русских своих освободителей от турецкого и персидского гнета. Не случайно, вскоре многие курды поступили на российскую военную службу и отли- чились отвагой и храбростью в многочисленных сражениях в ходе русско-турецких войн.

Значительное число курдов-езидов ${ }^{1}$ бежало в Армению и Грузию уже после Первой мировой войны, спасаясь от религиозно-этнических чисток и политических преследований со стороны турецких властей. Курды также проживали в ряде уездов бывшей Елисаветпольской губернии Российской империи, где в советское время образовался Азербайджан.

Таким образом, Советская Россия унаследовала от Российской империи вместе с другими народами, народностями и этносами и курдский народ с его богатой культурой, языком, нравами, обычаями и традициями. Несмотря на братоубийственную гражданскую войну и последовавший новый передел государственных границ уже советского Закавказья с Турцией, большая часть оставшихся в СССР курдов смогла не только выжить, но и успешно адаптировалась к новым социально-политическим условиям. Советские курды получили

\footnotetext{
По данным Института этнографии АН СССР езиды (йезиды) представляют собой особую конфессиональную общину внутри курдского этноса. Их верования чрезвычайно синкретичны, они как бы сочетают в себе отдельные элементы ислама, иудаизма, христианства, зороастризма и язычества. Советские езиды проживали в основном в Армении и Грузии и насчитывали к 1989 г. свыше 30 тыс. человек.
} 
возможность мирно жить и развиваться на своей исторической родине, в 1921 г. новыми властями была оказана помощь голодающим курдам продовольствием, постепенно налаживался их быт, преодолевалась вековая неграмотность, открывались школы, техникумы, фельдшерские пункты, больницы, на курдском языке издавались книги, газеты («Советский Курдистан»), велись радиопередачи, создавались другие культурные и просветительские учреждения. Уделялось внимание работе с национальными кадрами, выделялись стипендии для обучения курдов в ВУЗах Москвы, Ленинграда, других советских городов, из числа их выпускников впоследствии формировались местные органы власти и интеллигенция.

В 1923 г. в составе Азербайджанской ССР на границе с Армянской ССР одновременно с образованием Нагорно-Карабахской автономной области (НКАО) был создан Курдистанский уезд с центром в поселке Абдаляр (позже переименованный в Лачин). Уезд получил широкую известность как «Красный Курдистан» и способствовал росту национально-освободительного движения курдов в Турции, Иране, на подмандатных территориях Франции (Сирия) и Великобритании (Ирак). Одной из причин создания курдской автономии в этом районе было стремление советских властей снизить остроту армяно-азербайджанского территориального противостояния, передав некоторые спорные районы «третьей» стороне и создав как бы «буферную зону» между армянами и азербайджанцами.

В Курдистанском уезде проживали компактно в основном курды-мусульмане, первым председателем Курдистанского уездного исполкома стал Гуси Гусейнали оглы Гаджиев. В состав этого уезда вошли такие районы-дайры как Каракышлак, Кельбаджар, Котурлу, Кубатлы, Курд-Гаджи и Муратханлы с преобладающим курдским населением. По результатам всесоюзной переписи 1926 г. общая численность советских курдов достигала 232 тыс. человек. Население Курдистанского уезда составляло 51,2 тыс. чел., из которых курды-37 470 тыс. (73,1\%), тюрки-13 520 (26,3\%), армяне-256 человек $(0,5 \%)$. Во всех районах, за исключением тюркоязычного Кубатлинского, курды составляли абсолютное большинство населения. По данным 1925 г. в Курдистанском уезде имелось 6 районов, 330 поселений, объединённые в 63 сельских совета. Социальная структура населения в значительной степени сохраняла племенной характер, часть курдов продолжала вести полукочевой образ жизни, многие проживали в пещерах и шатрах.
Одновременно очаги курдской культуры и школы с обучением детей на диалектах курдского языка создавались и в других советских республиках, где были курдские общины: Армения, Грузия, Туркмения. И, если первые годы советской власти дали большой толчок развитию курдов как самобытного этноса, то к началу 30-х годов XX века картина стала постепенно меняться.

С молчаливого согласия руководства страны республиканские власти Закавказья приступили к постепенной ассимиляции своих малых народов. В Азербайджанской ССР был взят курс на тюркизацию курдов ${ }^{2}$. Аналогичные процессы с учетом местной специфики имели место и в других советских республиках, где проживали курдские общины (Армения, Грузия, Туркмения). Не случайно, что именно с этого времени многие фамилии курдов стали получать окончания «оглы», «ев», «ов», «ян», «швили», «дзе» и т.п.

Соответственно, и Курдистанский уезд просуществовал сравнительно недолго, будучи упразднённым уже 8 апреля 1929 г. решением VI Всеазербайджанского съезда советов ${ }^{3}$. Совнарком и ЦИК СССР утвердили это решение 23 июля 1930 г. Однако, представления о курдской автономии в СССР в 1923-29 гг. как о попытке справедливого решения курдского вопроса в рамках одной страны вошли в историю курдского национального движения и составляют важный сегмент исторической памяти курдов.

30-е годы прошлого столетия в СССР характеризовались усилением репрессий сталинского режима по отношению к советскому народу. И, если ранее преследовались группы населения по классовому и социальному признакам, то теперь «врагами народа» или «неблагонадежными элементами» объявлялись целые этносы, народности и народы. Не обошла эта беда и курдский этнос, который разделил судьбу десятков других советских репрессированных народов ${ }^{4}$. Большая часть

\footnotetext{
2 Необходимо учитывать высокую степень ассимиляции курдских племён, проникавших на горные территории Закавказья после присоединения края к Российской империи. К примеру, некоторые из них, обосновавшиеся на территории Кельбаджарского и Лачинского районов, к моменту проникновения на эти земли уже были тюркоязычными.

3 Бабаян Д. Красный Курдистан: геополитические аспекты создания и упразднения // http://www.noravank. $\mathrm{am} / ? \mathrm{l}=2 \& \mathrm{~d}=19 \& \mathrm{f}=245$

4 Репрессированные народы - по определению Закона РСФСР «О реабилитации репрессированных народов» от 26 апреля 1991 г. народы (нации, народности или этнические группы и иные исторически сложившиеся культурно-этни-
} 
советских курдов, главным образом мусульман, была выселена из мест постоянного проживания в 30-40-х годах прошлого столетия в малопригодные для жизни районы Средней Азии (Казахстан, Узбекистан и Киргизию). Сохранились лишь общины курдов-езидов в Армении и Грузии.

Через несколько лет после смерти Сталина, в 1956 году, курды, как и ряд других репрессированных народов, были формально реабилитированы (вначале без права возвращения на родину и компенсации имущественных потерь), а позже - большая их часть все же была частично восстановлена в правах. К сожалению, советские власти не смогли организовать эффективной программы реабилитации репрессированных народов, более того, возникла социальная напряженность как в местах бывших спецпоселений, так и в местах исторического проживания народов, когда у них появилась правовая возможность все же вернуться на свою малую родину.

Положение усугублялось тем, что в последние годы существования СССР республиканские элиты пытались спекулировать на национальных различиях, искусственно разжигали этно-конфессиональную вражду между группами населения, в этот период заметно активизировались националистические и экстремистские группировки, которые провоцировали погромы по национальному признаку и этнические чистки.

В весьма сложном положении оказались и советские курды, которым, как оказалось, возвращаться было просто некуда. Вначале азербайджанские республиканские власти всячески препятствовали возвращению курдов в Азербайджанскую ССР, в частности в районы Нахичевани и Лачина, откуда они ранее были выселены, позже возник армяно-азербайджанский вооруженный конфликт из-за статуса Нагорного Карабаха и часть курдских земель оказалась уже под контролем вооруженных сил Армении. Не приветствовали возвращение курдов-мусульман и грузинские власти. Большая часть курдов вынуждена были

ческие общности людей), в отношении которых проводилась государственная политика клеветы и геноцида, сопровождавшаяся их насильственным переселением, упразднением национально-государственных образований, перекраиванием национально-территориальных границ, установлением режима террора и насилия в местах спецпоселения. Все акты союзных, республиканских и местных органов и должностных лиц, принятые в отношении репрессированных народов, за исключением актов, восстанавливающих их права, признаются неконституционными и утрачивают силу. остаться в советских среднеазиатских республиках или рассеяться небольшими общинами на всем советском пространстве, включая ряд краев и областей РСФСР. Согласно переписи 1989 г. в СССР курдов официально насчитывалось 153 тыс. человек, однако с учетом насильственно ассимилированных курдов и курдов-езидов их число оценивалось в 300-500 тыс. человек. ${ }^{5}$

Представители курдских общественных организаций и интеллигенции неоднократно обращались в высшие законодательные и исполнительные органы СССР и Азербайджанской ССР с просьбами восстановить курдскую автономию или хотя бы обеспечить возвращение курдов к местам их исторического проживания. Большая часть этих обращений оставалась без ответа, на некоторые письма следовали формальные отписки. Со второй половины 80-х годов прошлого столетия, когда в стране началась эпоха демократизации, гласности, вошедшая в историю как «перестройка», у советских курдов появилась надежда все же добиться восстановления своих законных прав в Советском Союзе. Особую остроту курдскому вопросу в СССР придавали факты притеснений и погромов курдов в республиках Средней Азии, угрозы насильственного выселения их из отдельных районов Армении, Грузии, Краснодарского края (Адыгея), других мест, где местные власти отказывали им в прописке по новому месту жительства и трудоустройстве.

Из числа многочисленных обращений курдских представителей к руководству СССР того времени хотелось бы выделить ряд наиболее типичных.

Так, в июне 1989 г. группа курдских общественных деятелей (Бабаев М.С., Мамедов А.А., Чатуев Ф.К., Садыхов З.А. и другие) обратились с заявлением к председателю Палаты Совета национальностей Верховного совета СССР Нишанову P.Н., в котором излагали конкретные факты изгнания и притеснения курдов Армении, Узбекистана, Киргизии, Краснодарского края РСФСР. В этом обращении курды просили также советские власти разрешить им воссоздать свою автономию в Азербайджане, причем с учетом того, что на территории бывшего Курдистанского уезда и Нахичеван-

\footnotetext{
5 Из докладной записки Председателя Комитета по межреспубликанским отношениям Совета Республик Верховного Совета СССР С.Пирмухамедова от 20 ноября 1991 года на имя Председателя Совета Республик ВС СССР А.Т.Алимжанова. Государственный архив РФ, фонд 9654, опись 6 , дело 313 , л. 40
} 
ской АССР проживают другие народы, выражали готовность осваивать безлюдные, безводные земли на берегах Каспийского моря. Курды обещали на условиях хозрасчета и долгосрочной аренды свободных земель наладить их орошение, производить продукты земледелия и животноводства, выплачивать государству налоги и арендную плату. ${ }^{6}$

4 июня 1991 г. Генеральный директор Центра курдской культуры Т.М.Броев обратился к Президенту СССР М.С.Горбачеву и Председателю Верховного Совета СССР А.И.Лукьянову с просьбой ускорить решение курдского вопроса в стране, в частности, восстановление курдской автономии и паритетного представительства курдов в законодательных органах власти на всех уровнях. ${ }^{7}$

Обращения курдов находили понимание среди законодателей и советской общественности. Так известный советский поэт и публицист, депутат Верховного Совета СССР, заместитель председателя Палаты Национальностей Верховного Совета СССР Олейник Борис Ильич в своем письме Президенту СССР и Генеральному секретарю ЦК КПСС М.С.Горбачеву от 26 апреля 1990 года выступил в поддержку чаяний и надежд советских курдов и поддержал их просьбу о личной встрече с руководителем государства. ${ }^{8}$

Все эти усилия не пропали даром и уже 23 октября 1990 г. вышло в свет Постановление Президиума Верховного Совета СССР № 1738-I «Об образовании Комиссии по проблемам курдского народа» во главе с заместителем Председателя Государственного комитета РСФСР по национальным вопросам, народным депутатом СССР Соболевым В. П.

После серии встреч с представителями курдов и поездок членов Комиссии в места их компактного проживания в своем Решении № 6/1 от 4 июля 1991 года Комиссия проинформировала Верховный Совет СССР о следующем: «Позитивных изменений в условиях жизни курдского населения не произошло, десятки тысяч курдов в результате межнациональных конфликтов оказались на положении беженцев, в более глубокой проработке нуждается основной вопрос - о восстановлении национально-территориального образования курдов». Помимо конкретных предложений по защите

\footnotetext{
6 Государственный архив РФ, фонд 9654, опись 6, дело 114, лист 30

7 Государственный архив РФ, фонд 9654, опись 6, дело 313, лист 14

8 Государственный архив РФ, фонд 9654, опись 6, дело 203, листы 7-9
}

прав и запросов курдов в Азербайджане, Казахстане, Киргизии, в Краснодарском крае и Адыгейской республике, Комиссия предложила рассмотреть вопросы, связанные с активизацией научных исследований проблем курдов в СССР, организацией обучения курдов на родном языке, подготовкой кадров из числа курдов для работы в сфере народного образования, науки и культуры, оказать содействие республикам в разработке соответствующих учебников, учебных пособий и методических материалов. ${ }^{9}$

Распад СССР в конце 1991 года не позволил реализовать планы и намерения руководителей советского государства по восстановлению исторической справедливости в отношении курдского народа. Политическая нестабильность и региональные конфликты постсоветского времени вынуждали часть советских курдов мигрировать в Россию, однако значительное их число все же осталось в странах Закавказья и Средней Азии.

Сегодня, по самым приблизительным оценкам, свыше 15 тысяч курдов и курдов-езидов проживает в Грузии. Они не испытывают какого-либо давления или попыток ассимиляции со стороны грузинских властей, но и активного участия в политической и общественной жизни страны не принимают. Переселение курдов из Грузии в Россию и другие постсоветские государства продолжается в основном по экономическим соображениям.

Гораздо больше, примерно, 150-250 тысяч курдов проживает в Азербайджане. Большая их часть ассимилирована, считается азербайджанцами, существует даже точка зрения, что ассимилированные курды занимают ведущее место в азербайджанской правящей элите. Один из руководителей курдской общины республики Ахмед Апиев заявлял, что курды в Азербайджане проживают лишь в нескольких селах в районах вокруг Гянджи, в Нахичеванской автономной республике и в местах временного расселения в Баку. Якобы, некоторое количество курдов было переселено также в районы Азербайджана, примыкающие к Нагорному Карабаху с севера, однако точное их количество не указывается. В случае гипотетического разрешения нагорно-карабахского конфликта на условиях Азербайджана говорить о воссоздании в какой-либо форме курдской автономии не представляется возможным: согласно конституции страна строится на унитарном принципе и статус ограниченной

\footnotetext{
9 Государственный архив РФ, фонд 9654, опись 6, дело 313,
} листы 30-31 


\section{Международные отношения / International Relations}

автономии прописан лишь для территориально отделённой Нахичевани.

1 марта 2013 года на базе Центра курдской культуры «Ронаи» состоялся очередной съезд курдов Азербайджана. На съезде обсуждались насущные проблемы курдов, выпуск газеты «Данге курд», создание курсов по изучению курдского языка в Баку и в районах компактного проживания курдов. Этой теме уделили внимание также старейшины и активисты курдского движения. По мнению собравшихся, центр должен играть существенную роль в жизни курдов Азербайджана, налаживать отношения с Иракским Курдистаном, курдскими меньшинствами в Турции, Иране, Сирии и курдскими общинами и диаспорами в странах СНГ и Европе. В ходе съезда было принято решение увеличить периодичность выпуска газеты до двух раз в месяц, образовать филиалы центра в регионах, открыть интернет-сайт и создать курдский ансамбль.

В Армении в основном проживают курды-езиды (30-40 тысяч человек). Вопрос о возможном возвращении реабилитированных курдов-мусульман в район, так называемого, Лачинского коридора, соединяющего Нагорный Карабах с Арменией, и на прилегающие к нему территории вряд ли будет рассматриваться до урегулирования армяно-азербайджанского конфликта.

В свое время армянские учёные внесли определённый вклад в поощрение собственно езидской идентичности ${ }^{10}$, а несколько позже - в формирование идентичности народа заза, также, согласно некоторым концепциям, отличным от воззрений курдов. Это воспринимается в курдских кругах весьма болезненно: армянская сторона обвиняется в попытках внести раскол в формирующуюся общекурдскую идентичность ${ }^{11}$.

10 Аракелова В. К истории формирования езидской общины // Иран-намэ: Армянский востоковедческий журнал. Ереван, 2006. № 40; Genetic Affinity between the Armenian Yezidis and the Iraqi Kurds // http://www.rau.am/downloads/ publ.kafedr/episkoposyan_medbiolog/Yepiskoposyan_2010_ Iran\%20\&\%20Caucasus.pdf и др.; интересно, что среди курдов, в частности в России и Грузии, есть немало случаев интереса к христианству и принятия православной веры, см. напр.: Серафим Маамди: Почему курды принимают православие // http://www.pravmir.ru/serafim-maamdi-pochemukurdy-prinimayut-pravoslavie/.

11 Вот что говорил в интервью газете «Новый Курдистан» один из сторонников курдского интегризма, д.ю.н., проф. Самвеле Кочои: «Напомню, в 1989 г. по итогам переписи населения Армении, Государственный комитет республики по статистике (Госкомстат) объявил, что в этой стране проживают 50- 60 тысяч езидов. Отдельно была указана числен-
Общая для армянских политиков и исследователей точка зрения состоит в том, что территории между Арменией и Нагорным Карабахом, о которых эпизодически вспоминают некоторые курдские активисты, не могут быть предметом торга в урегулировании нагорно-карабахского конфликта, поскольку от них зависит безопасное и поступательное развитие всего армянского народа.

Формирование курдских общин Средней (Центральной) Азии стало результатом трагических событий, связанных с депортациями и насильственными выселениями курдов с территории Южного Кавказа. Курдские специальные поселения и комендатуры были размещены в более чем сотне районов всех республик Средней Азии с тем, чтобы не создавать компактных мест проживания курдов. Крайне неблагоприятные условия существования в спецпоселениях не помешали курдам сохранить свой язык, обрядность, традиции, религию. Безусловно, невозможность получить образование и совершенствовать свои знания существенно замедлили процесс общего развития спецпоселенцев. В настоящее время в регионе проживает около 150 тысяч курдов, больше половины из них - в Казахстане (преимущественно на юге республики - Алма-Атинская, Чимкентская и Джамбульская области). В последние годы они получили возможность свободно развивать свою национальную культуру, создавать общественные организации, ассоциации, СМИ, вести издательскую деятельность. Например, в Казахстане издаются журнал «Курды» и газета «Курдистан», действуют культурные центры, имеются художественные ансамбли, готовятся национальные кадры. Курды принимают активное участие в деятельности Ассамблеи народов Казахстана. Курдские культурные центры Казахстана в 1993 г. объединились в Ассоциацию «Якбун» (Единство), переименованную в 1999 г. в «Барбанг». Возглавляет Ассоциацию профессор Мирдоев К.И.

В 1993 г. под названием «Ныштыман» (Отечество) была создана «Ассоциация курдов Республики Кыргызстан». Позже, согласно распоряжению

ность проживающих там курдов. Таким образом, в Армении при попустительстве и с участием властей официально был оформлен раскол курдского общества по конфессиональному признаку. Причем линия раздела была проведена не только между мусульманами и езидами, но и самими езидами, поскольку большинство последних себя считало (и продолжает считать) курдами...» Между тем, как бы то ни было, наличие особой езидской этнокультурной идентичности вряд ли вызывает сомнения у серьёзных учёных. 
Политическая стабильность / Political stability

правительства страны о переименовании всех ассоциаций в общественные объединения, Ассоциация была переименована в «Общественное объединение курдов Республики Кыргызстан». В 2001 г. объединение возглавил член Национального конгресса Курдистана, советник президента Киргизии по национальным вопросам Рамазан Сеидов. По его словам, «самым большим достижением Объединения является еженедельное вещание радиопередач на государственном радио на курдском языке».

В Узбекистане курды-спецпоселенцы были распределены по 7 областям и 43 районам республики, в частности, в Ташкентской, Самаркандской, Ферганской и Бухарской областях. В настоящее время количество курдов в этой стране, по-видимому, не так велико (по оценкам, всего несколько тысяч).

Рост национального самосознания курдов Средней Азии проявляется в самых разных формах, включая оказание гуманитарной помощи сирийским соплеменникам и активное выражение позиции по различным вопросам общественно-политической жизни своих стран. Напряженность в отношениях курдов с коренным населением среднеазиатских республик в последнее время заметно спала, открытых конфликтов и вспышек насилия на национальной почве не отмечается.

Курды Украины (по оценкам главы общины - до 30 тысяч человек), проживают относительно компактно в Киеве - более 5000, Одессе, Николаеве, Запорожье, Херсоне. Они активно выражают свои гражданские позиции в связи с событиями на исторической родине и вокруг неё. Президентом Ассоциации курдских общественных организаций Украины «Мидия» (основана в 1995 году) является Георгий Гасанов. 65-70\% курдского населения страны - выходцы из бывших советских республик, 30 \% - представители «дальнего зарубежья». Актуальной проблемой общины является легализация нелегальных мигрантов (от четверти до трети общего количества курдов Украины). Несмотря на доминирование в их среде курдов-езидов (две трети общины), разногласий с курдами-мусульманами не имеется. Украинские курды сохраняют определённую дистанцию от остального населения (в частности, не приветствуются смешанные браки, внутри общины действует совет старейшин, вердикт которого имеет силу закона). Основная специализация общины - сельское хозяйство и бизнес, в крупных городах приобретает популярность получение высшего образования, профессий, связанных с интеллектуальным трудом (юристы, предприниматели, помощники народных депутатов Украины).

Первые курдские общины на территории Российской Федерации появились во второй половине XX века. На период проведения переписи 1979 года на территории РСФСР существовала, как минимум, одна компактная группа курдов - в станице Пшехской Белореченского района Краснодарского края. В тот период в Краснодарском крае проживало 539 курдов, из них 48 - в городах и 491 - в сельской местности. Согласно исследованию М. Саввы, в станице Пшехской и нескольких близлежащих населенных пунктах проживало 546 курдов-446 мусульман и 100 езидов. Первые семьи курдов-мусульман прибывали в Краснодарский край из Узбекистана, Казахстана и Киргизии в 1968-1969 годах, куда они ранее были депортированы из Грузии. Причиной переселения курдов из Средней Азии именно на Кубань курды-мусульмане называли наличие здесь хороших условий для занятий сельским хозяйством. Курды-езиды, жившие в станице Пшехской, переселились на Кубань из Армении, куда, в свою очередь, они переходили в течение длительного времени вместе со своими землями из турецкого и иранского Курдистана и Азербайджана ${ }^{12}$.

Курды Адыгеи имеют свою общественную организация «Агры», находящуюся в селе Белом, Красногвардейского района республики Адыгея. Села Белое и Садовое, компактно заселенные курдскими переселенцами, расположены у трассы P253 (Майкоп-Усть-Лабинск-Кореновск). Другим заметным местом компактного поселения курдов является Тамбовская область (более 5 тыс. чел.), где обосновались курдские переселенцы из Казахстана и Армении (в том числе и в рамках программы по переселению соотечественников), занимающиеся сельским хозяйством, животноводством, а также дорожно-строительными работами. На территории одного из поселков общины имеется уменьшенная копия езидского храма Лалеш (северный Ирак). Большим влиянием и авторитетом в области пользуется крепко связанный с региональными властями бизнесмен Джамал Шамоян, фирмы которого (Союз многоотраслевых хозяйственных предприятий «Дижла») неоднократно выигрывали тендеры на ремонт и строительство

12 Курды в Краснодарском крае. Исследования. Сборник информационно-методических материалов. - Краснодар: ЮРРЦ, 2007. 


\section{Международные отношения / International Relations}

дорог области, получая прямое финансирование из местного бюджета.

Однако, согласно переписи 2010 года общая численность лиц, которые по национальности назвались курдами, составила в РФ всего лишь 23232 человек (0,002\% населения России). Из них в городах-4095 человек, а в сельской местности-19137 человек. Численность лиц, отмеченных в переписных листах по национальности езидами, составила 40586 человек $(0,003 \%$ населения России), из них горожане-22452 человек и сельчане-18 134 человек. Курды и курды-езиды оказались расселены в Российской Федерации в основном в Астраханской, Ярославской, Ростовской, Саратовской, Тамбовской, Новосибирской, Курской, Московской, Ленинградской и других областях, Краснодарском и Ставропольском краях. Значительное число курдов проживает в Москве и Санкт-Петербурге.

Неофициальные оценки общего количества курдов на территории Российской Федерации до 200 тыс. человек. ${ }^{13}$ Вот некоторые характеристики курдской этнической общности: численное превалирование мужчин (58\%), довольно низкая степень урбанизации (59\% горожан), высокий удельный вес владеющих родным языком-82,5\%. Строгая моноэтничность браков позволяет курдам поддерживать высокий уровень национального самосознания и противостоять ассимиляционному воздействию со стороны.

По мере становления российской государственности и строительства гражданского общества курды в России стали проявлять себя все более активно в социальном плане, выступать с общественными инициативами, сотрудничать с российскими государственными и общественными организациями на федеральном, региональном и местном уровнях, создавать собственные общественные структуры, объединенные в так называемый «Курдский дом» (Международный союз курдских общественных объединений). В Москве концентрируется значительная часть курдской интеллигенции, регулярно в «Курдском доме», Президент-отеле, Дипломатической академии МИД РФ, Институте востоковедения РАН, ИМЭМО РАН, РИА-Новости, на других площадках проводятся научные конференции, семинары, круглые столы по актуальным вопросам курдского сообщества с участием политиков, ученых, общественных деятелей, представителей СМИ из России, Ирака, Турции, Си-

13 Курды тамбовской земли // http://www.youtube.com/ watch?v=Meab-EEmxkU рии, гостей из стран СНГ и ЕС. Несмотря на свою относительную малочисленность, российские курды весьма активны и заметны в российском обществе. Многие их представители добились всероссийского и мирового признания: доктор технических наук, философ, филолог Д.Г.Лахути, доктор филологических наук, ученый-курдовед, специалист по диалектам курдского языка 3.А.Юсупова, капитан 1 ранга в отставке, писатель, историк, публицист К.Б.Раш, кандидат философских наук, преподаватель Санкт-Петербургского государственного университета Х.Р.Омархали (Усоян), крупный предприниматель, депутат Государственной Думы Федерального Собрания РФ уже нескольких созывов 3.А.Муцоев и сотни других.

Федеральные, региональные и местные органы власти учитывают курдский фактор в своей социальной и национальной политике. В настоящее время достаточно остро стоит проблема «позитивной» узнаваемости курдов, выстраивания соответствующих коммуникационных каналов, которыми в первую очередь являются СМИ. У курдов России выходит двуязычное печатное издание - ежемесячная газета «Свободный Курдистан» (на русском и курдском языках, тираж 2000 экз.). Информационные ресурсы курдской диаспоры представлены весьма качественными русскоязычными сайтами (новостные, информационно-аналитические, развлекательные, сайт знакомств и др. Государственная радиокомпания «Голос России» пока вещает на нескольких диалектах курдского языка лишь на зарубежную аудиторию.

Рассматривается вопрос об оказании российским курдам и курдским общественным организациям государственной поддержки, а также помощи по линии неправительственных и общественных организаций РФ. Очевидно, что курдыпереселенцы еще долгое время будут нуждаться в государственной опеке, а в отдельных случаях и в защите от произвола местных чиновников и полукриминальных структур. С другой стороны, формально не имеется и каких-либо препятствий к последующей адаптации курдов в России и деятельности их общественных организаций. Теоретически они в полной мере могут пользоваться правами, предоставляемыми законом «О национально-культурных автономиях». В общем виде позиция властей сводится к тому, что курдская диаспора в России имеет право на свои культурные и просветительские организации, безусловно, при условии соответствия их деятельности российским законам. 


\section{Политическая стабильность / Political stability}

\section{Библиография}

1. Бабаян Д. Красный Курдистан: геополитические аспекты создания и упразднения // http://www. noravank.am/?l=2\&d=19\&f=245

2. Докладная записка Председателя Комитета по межреспубликанским отношениям Совета Республик Верховного Совета СССР С. Пирмухамедова от 20 ноября 1991 года на имя Председателя Совета Республик ВС СССР А.Т.Алимжанова. Государственный архив РФ, фонд 9654, опись 6, дело 313. Государственный архив РФ, фонд 9654, опись 6, дело 114, лист 30

3. Государственный архив РФ, фонд 9654, опись 6, дело 313.

4. Государственный архив РФ, фонд 9654, опись 6, дело 203.

5. Аракелова В. К истории формирования езидской общины // Иран-намэ: Армянский востоковедческий журнал. Ереван, 2006. № 40.

6. Genetic Affinity between the Armenian Yezidis and the Iraqi Kurds // http://www.rau.am/downloads/publ. kafedr/episkoposyan_medbiolog/Yepiskoposyan_2010_Iran\%20\&\%20Caucasus.pdf

7. Серафим Маамди: Почему курды принимают православие // http://www.pravmir.ru/serafim-maamdipochemu-kurdy-prinimayut-pravoslavie/.

8. Курды в Краснодарском крае. Исследования. Сборник информационно-методических материалов. Краснодар: ЮРРЦ, 2007.

9. Курды тамбовской земли // http://www.youtube.com/watch?v=Meab-EEmxkU

10. Манойло А.В. Политические конфликты в международных отношениях и мировой политике. //Мир и Политика. 2013. №2. С. 71-82.

11. Манойло А.В. Глобальная нестабильность на пороге новой большой войны. // Мир и политика. 2012. - №12. - С. 87-89.

12. Гушер А.И. Вызовы и угрозы безопасности России // NB: Международные отношения. - 2014. - 1. C. 64-75. DOI: 10.7256/2306-4226.2014.1.10748. URL: http://www.e-notabene.ru/wi/article_10748.html

13. Манойло А.В. Стратегии «управляемого хаоса» в условиях хаотизации международных отношений: миф или реальность? // NB: Международные отношения. - 2014. - 1. - С. 1-3. DOI: 10.7256/23064226.2014.1.10750. URL: http://www.e-notabene.ru/wi/article_10750.html

References

1. Babayan D. Krasnyi Kurdistan: geopoliticheskie aspekty sozdaniya i uprazdneniya // http://www.noravank. am/?l=2\&d=19\&f=245

2. Dokladnaya zapiska Predsedatelya Komiteta po mezhrespublikanskim otnosheniyam Soveta Respublik Verkhovnogo Soveta SSSR S. Pirmukhamedova ot 20 noyabrya 1991 goda na imya Predsedatelya Soveta Respublik VS SSSR A.T.Alimzhanova. Gosudarstvennyi arkhiv RF, fond 9654, opis' 6, delo 313. Gosudarstvennyi arkhiv RF, fond 9654, opis' 6, delo 114, list 30

3. Gosudarstvennyi arkhiv RF, fond 9654, opis' 6, delo 313.

4. Gosudarstvennyi arkhiv RF, fond 9654, opis' 6, delo 203.

5. Arakelova V. K istorii formirovaniya ezidskoi obshchiny // Iran-name: Armyanskii vostokovedcheskii zhurnal. Erevan, 2006. № 40.

6. Genetic Affinity between the Armenian Yezidis and the Iraqi Kurds // http://www.rau.am/downloads/publ. kafedr/episkoposyan_medbiolog/Yepiskoposyan_2010_Iran\%20\&\%20Caucasus.pdf

7. Serafim Maamdi: Pochemu kurdy prinimayut pravoslavie // http://www.pravmir.ru/serafim-maamdipochemu-kurdy-prinimayut-pravoslavie/.

8. Kurdy v Krasnodarskom krae. Issledovaniya. Sbornik informatsionno-metodicheskikh materialov. Krasnodar: YuRRTs, 2007.

9. Kurdy tambovskoi zemli // http://www.youtube.com/watch?v=Meab-EEmxkU

10. Manoilo A.V. Politicheskie konflikty v mezhdunarodnykh otnosheniyakh i mirovoi politike. //Mir i Politika. 2013. №2. S. 71-82.

11. Manoilo A.V. Global'naya nestabil'nost' na poroge novoi bol'shoi voiny. // Mir i politika. - 2012. - №12. S. 87-89.

12. Gusher A.I. Vyzovy i ugrozy bezopasnosti Rossii // NB: Mezhdunarodnye otnosheniya. - 2014. - 1. - C. $64-75$. DOI: 10.7256/2306-4226.2014.1.10748. URL: http://www.e-notabene.ru/wi/article_10748.html

13. Manoilo A.V. Strategii «upravlyaemogo khaosa» v usloviyakh khaotizatsii mezhdunarodnykh otnoshenii: mif ili real'nost'? // NB: Mezhdunarodnye otnosheniya. - 2014. -1.-C.1-3. DOI: 10.7256/2306-4226.2014.1.10750. URL: http://www.e-notabene.ru/wi/article_10750.html 